\title{
French minister plans shake-up for research
}

Declan Butler and Sally Goodman, Paris

Claudie Haigneré, who became minister for research in France's new centre-right government in June, was the nation's first female astronaut and is the only woman qualified to pilot the International Space Station's Soyuz lifeboat back to Earth.

Now she's on an emergency mission of a different sort. She is aiming to rescue the country's research system from a set of problems that many observers say are preventing France from keeping its best young talent or from punching its weight internationally.

Haigneré's aim is to rebuild relations between her ministry and the research community, and then bring about change with the backing of scientists. "I'm aware of the imperfections of the system, but we can't change it with a magic wand," she says. She has pledged not to micromanage the various agencies supervised by the ministry, but rather to render them accountable by evaluating their performance in reaching set goals.

Haigneré is a calm, unassuming character. But her professional track record suggests that this political debutante may just have the nerve and tenacity to get the job done.

She topped her class at the University of Dijon medical school, and practised in rheumatology and sports injuries before gaining a $\mathrm{PhD}$ in neuroscience and a research position at a lab run by the CNRS, France's national research agency, in Paris. In 1985, Haigneré was chosen from 1,000 applicants to become an astronaut. While training, she led medical research at the French space agency.

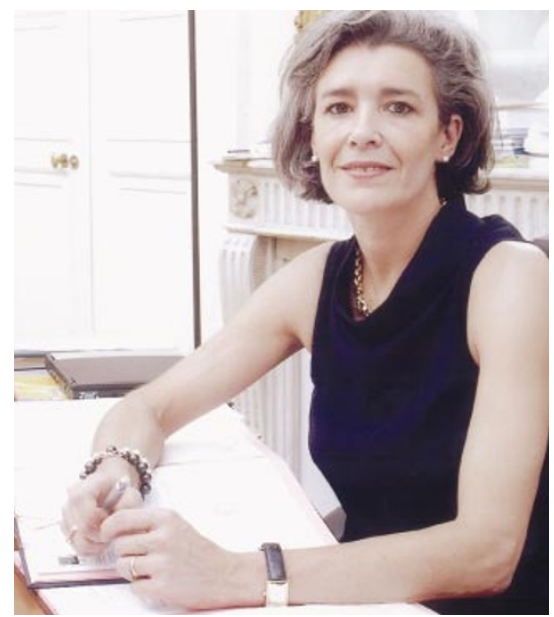

New mission: former astronaut Claudie Haigneré is now at the helm of France's research ministry.

Haigneré has pledged that her approach will be forged by the "patience, determination, continuity of effort, and teamwork" that she learned from preparation for space missions. She is seen as a reformer - but one in a very different mould from the geophysicist Claude Allègre, who attempted a radical overhaul of French research, without the backing of researchers, during his tenure as minister from 1997 to 2000 (seeNature 404, 421;2000).

One of Haigneré's goals will be greater autonomy for young researchers. Almost 75\% of full-time researchers in France work in the laboratory where they obtained their $\mathrm{PhD}$. Because most funds are spread thinly across laboratories, rather than going to individual investigators as competitive grants, young researchers often find themselves subservient to powerful senior scientists. As a result, critics say, many of France's best young talents disappear abroad and do not return.

Haigneré says she would like to break this pattern and offer the best young scientists higher salaries, larger grants and better working conditions. She favours the creation, for the first time, of a full-blown postdoctoral system in France, but does not plan to challenge the civil-servant status and good job security currently enjoyed by public researchers.

The time may be ripe for such a pragmatic approach to reform, says Daniel Louvard, director of the Curie Institute in Paris. What's needed, he says, is not wholesale change, but rather a set of discrete measures that will "encourage young scientists to take risks and give them good reasons to work in France".

But Haigneré's ambition maybehampered by the likelihood that next year's science budget will be unchanged or even reduced, potentially jeopardizing an agreement between scientists and the previous government to increase the number of research positions.

Researchers are already complaining that President Jacques Chirac has reneged on a promise, made before his re-election in May, to increase total spending on research and development from 2.15\% of France's economy to $3 \%$ by 2010 . Haigneré says most of this increase will come from industrial spending, but admits it will be difficult to meet the target unless the public research budget also grows.

\section{Scientists seek safety in secrets of the soundbite}

\section{David Adam, London}

A scare over the safety of a widely prescribed medicine is gripping the nation. As a prominent scientist, you're being interviewed live on television. Then comes the dreaded question: "Is it safe?". How do you respond? Insist that it is and risk sounding dismissive? Reach for a reassuring statistic and be accused of hiding behind numbers? Or admit that “we just don't know", and satisfy nobody?

Help may soon be at hand. Late last month, a group of scientists, journalists, politicians and risk-management experts met at London's Science Media Centre to discuss how to handle this question. The centre, launched in April by the Royal Institution to improve representation of science in the media, intends to use the results in a leaflet on how best to communicate risk. "When scientists are asked the question 'is it safe' and realistically it is, then we want to give them some options to draw on," says Fiona Fox, the centre's head.

Three volunteers agreed to undergo mock interviews at the hands of BBC science correspondent Pallab Ghosh, who confronted them with a barrage of questions on issues that have captured the media's attention in the past six months: the risk associated with the combined measles, mumps and rubella (MMR) vaccine, hormone-replacement therapy (HRT) and railway safety.

Opinions varied as to how the risks involved should be communicated. Some said that a humble "in my opinion" or an "I am confident" help to suggest relative safety. Others recommended relating the risk to other activities - "I've already done five riskier things today," said Colin Berry, a pathologist at the Royal London Hospital. And Evan Harris, the Liberal Democrat science spokesman and Member of Parliament for Oxford West, said phrases such as "if you think sex is risky you should try lifelong celibacy" can help to make clear the benefits of taking a particular risk.

Other phrases that went down well with the audience included "breast cancer is a risk of being alive", and "I can understand that people are worried but...”. For MMR, the participants liked the idea of stressing the fact that several studies had looked for a link with autism, but none had found one. But scientific jargon, such as "uncertain in a compound way", is best avoided, the audience said. One participant was advised against describing the risk associated with rail travel as "unquantifiable" - even if the statement is technically correct.

As well as preparing suitable answers, Ghosh said that scientists should bear in mind that they are talking to the audience, not the interviewer. But Harris added that addressing all of the audience is impossible. "There are some people that you can never and will never persuade, whatever the 


\section{Climate model under fire as rains fail India}

\section{K. S. Jayaraman, New Delhi}

As much of southern Asia faces its worst drought for 30 years, the Indian government is being heavily criticized for its reliance on a statistical model to forecast the monsoon.

The India Meteorological Department (IMD), based in New Delhi, uses the model to issue a forecast of the monsoon every spring. This May it issued a prediction saying that rainfall would be $101 \%$ of normal. But by 6 August, this forecast remained way off the mark, with about three-quarters of the country having received very little rain.

Most of India's rain falls during the summer monsoon season between June and September, with July typically accounting for half of the annual total. But this season has been unusually dry, and last week's heavy rain and flooding in some areas are unlikely to save the harvest, most observers say. An accurate forecast of the impending drought would have allowed farmers to switch to more resilient crop varieties, as well as giving the authorities more time to prepare for a potentially poor harvest.

The IMD's statistical model is based on past weather patterns. It tracks 16 factors thought to have some influence on the monsoon, ranging from the amount of snow lying on the Himalayas to the status of the El Niño climate pattern in the eastern Pacific Ocean.

Many researchers point out that the prediction of extreme events - such as the failure of the rains - will always be challenging for this type of model. But some are now

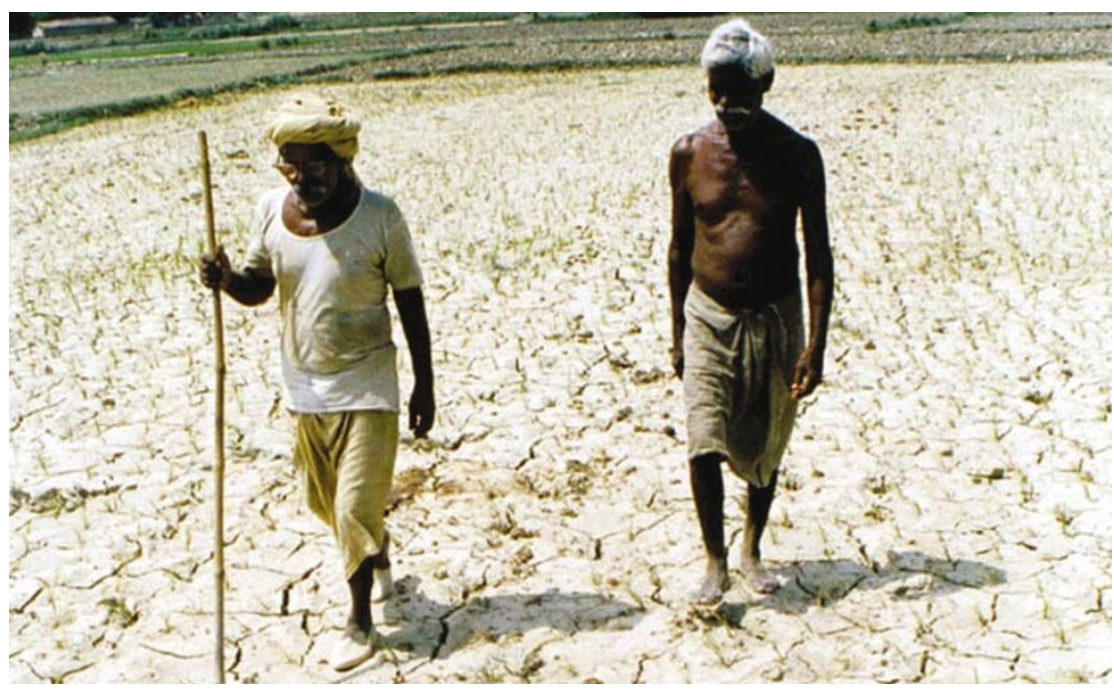

Poor prediction: the Indian government failed to forecast this year's drought, the worst for 30 years.

questioning the IMD's choice of criteria, and others say that the government should switch to more sophisticated generalcirculation models (GCMs). These calculate the evolution of the ocean-atmosphere system by combining dynamic equations with data on initial conditions.

"The real challenge in long-range monsoon forecasting is to predict the extreme drought events," says J. Srinivasan, a climatologist at the Indian Institute of Science in Bangalore. "Because we had normal or above normal rainfall for the past 14 years, we may have placed more faith in statistical evidence, so I try and give answers to the large number of people who are swayable," he said.

Statistics provoked the most heated debate. Some argued that figures bring much-needed perspective; others said that

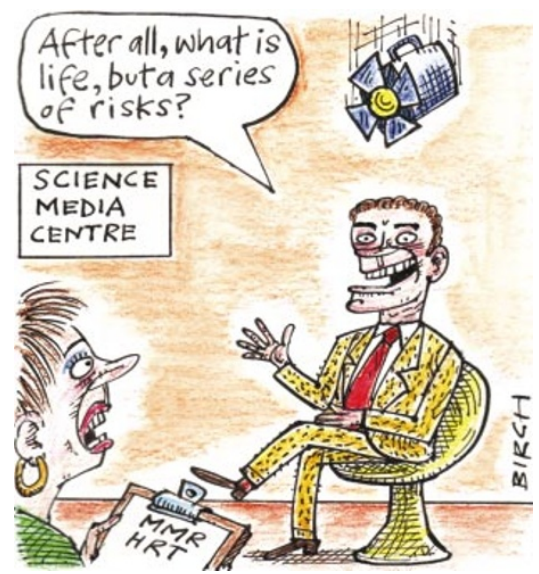

they cloud the issue. For example, media coverage of the suspension of a recent US HRT trial focused on the apparently alarming $26 \%$ increase in the incidence of breast cancer, although this is equivalent to just 8 extra cases per 10,000 women.

Some scientists have already proved to be capable of putting such figures into context. In a 10 July interview on BBC Radio's Today programme, David Purdie, an obstetrician and gynaecologist at the Hull Royal Infirmary, discussed with interviewer John Humphrys the apparently huge increases in risk posed by HRT trials. The figures, he said, are an example of "the Judas factor" - a small number of cases can cause an alarmingsounding percentage if the total number of samples is small. "Christ was betrayed by 8.5\% of his disciples," Purdie told Humphrys. "But when you consider how many actually did the job, it was just one out of 12."

www.sciencemediacentre.org models than we ought to have done."

But the government is playing down the failure of this year's prediction. "It is unfair to blame the model on the basis of one failed forecast in 15 years," says Valangiman Ramamurthy, secretary of the Department of Science and Technology (DST), which oversees the IMD. "We will review the model at the end of the season." He concedes that an effort is already under way to refine the model, however, noting that four of its 16 criteria were changed two years ago.

S. M. Kulshrestha, former director of the IMD, notes that a high degree of variability is intrinsic to the monsoon. "You can throw the model away, but there is nothing to replace it with," he says.

Most researchers see GCMs as the best long-term bet for monsoon prediction, although GCMs cannot yet predict monsoon failure accurately. But they believe that these predictions will improve as more observations are made, the models become more detailed and computers increase in power.

GCMs are already showing some promise. This year, for example, the European Centre for Medium-Range Weather Forecasts model predicted normal Indian rainfall based on conditions on 1 May, but below normal based on 1 June conditions. "This indicates that this year's below normal rainfall occurred on account of changes in atmospheric circulation during May," says Srinivasan.

Officials still doubt whether GCMs can replace the statistical model in the short term. There are lots of GCMs "but no consensus about which one to use", says Dev Raj Sikka, head of the DST's climate-research programme. Nevertheless, Indian scientists agree that this year's unusual monsoon conditions will provide useful data on which to base future predictions. 